\title{
Table of policy documents
}

\section{EUROPEAN COMMISSION}

An energy Policy for the European Union, Brussels, 13.12.1995, COM(95) 682

Better Regulation - simply explained, 2006

Better regulation for better results - An EU agenda, Strasbourg, 19.5.2015, $\operatorname{COM}(2015) 215$ 158

Better Regulation Guidelines. Commission Staff Working Document, Strasbourg, 19.5.2015, SWD (2015) 111

BREF for Large Combustion Plants, Industrial Emissions Directive 2010/75/EU, Draft 1 (June 2013) 165

BREF on Management of Tailings and Waste- Rock in Mining Activities (2009) 165-6, 192

Communication on Energy 2020 - A strategy for competitive, sustainable and secure energy, Brussels, 10.11.2010, $\operatorname{COM}(2010) 639$ 65

Communication on Energy Union Package - A framework strategy for a resilient energy union with a forward-looking climate change policy, Brussels, 25.2.2015, $\operatorname{COM}(2015) 80$ 66

Communication on the exploration and production of hydrocarbons (such as shale gas) using high volume hydraulic fracturing in the EU, Brussels, 17.3.2014, $\operatorname{COM}(2014) 23$ $5,61,112,174,183,192$

Communication on the Future of Carbon Capture and Storage in Europe, Brussels, 27.3.2013, $\mathrm{COM}(2013) 180$ 137,168

Communication on the precautionary principle, Brussels, 2.2.2000, $\operatorname{COM}(2000)$ 1 105,112

Communication on the regulatory aspects of nanomaterials, Brussels, 17.6.2008, $\operatorname{COM}(2008) 366$

Communication on the short-term resilience of the European gas system Preparedness for a possible disruption of supplies from the East during the fall and winter of 2014/2015, Brussels, 16.10.2014, COM(2014) 654

Energy Roadmap 2050, Brussels, COM(2011) 885/2 65-6, 68

Ensuring safe and environmentally sound CCS, DG CLIMA 87,119

European Energy Security Strategy, Brussels, 28.5.2014 69-70

European Governance - A white paper, COM(2001) 428, OJ C 287 , 12.10.2001

European Governance: Better lawmaking, COM(2002) 275 158

A European Strategy for Sustainable, Competitive and Secure Energy, Brussels, 8.3.2006, COM(2006) 105 5,61

First guidelines for a Community Energy Policy, (1968), COM (68) 1040 63 
Impact Assessment -Accompanying document to the Proposal for a Directive on the geological storage of carbon dioxide, Brussels, 23.1.2008,

$\operatorname{COM}(2008)$ $129-130$

Impact Assessment, Exploration and production of hydrocarbons (such as shale gas) using high volume, hydraulic fracturing in the EU, Brussels, 22.1.2014, SWD(2014)21

Implementation of Directive 2009/31/EC on the Geological Storage of Carbon

Dioxide Guidance Document 1 - CO2 Storage Life Cycle Risk Management

Framework, 2011 $120-21$

Implementation Report from 2007 on the nanotechnology action plan, Brussels, 6.9.2007, $\operatorname{COM}(2007) 505$

The Internal Energy Market, Commission Working Document, Brussels, 2.5.1988, COM (88) 238

Nanosciences and nanotechnologies: an Action Plan for Europe 2005-2009

(COM(2005) 243)

86,132

Public Awareness and Acceptance of $\mathrm{CO} 2$ capture and storage (Special Eurobarometer, 2011)

Recommendation 2011/696/EU on the definition of nanomaterial, [2011] OJ L275/ 38

Recommendation on a Code of Conduct for responsible nanosciences and nanotechnologies research, $\mathrm{C}(2008) 424$ $7,86,129,132,190$

Recommendation on the definition of nanomaterial, [2011] OJ L 275/38 .... 86

Recommendation on minimum principles for the exploration and production of hydrocarbons (such as shale gas) using high-volume hydraulic fracturing, OJ [2014] L39/72 (22 January 2014) $31,39,43-4,99,111,129,163,189$

Renewable Energy Road Map - Renewable energies in the 21st century: building a more sustainable future, Brussels, 10.1.2007, COM(2006) 848 66,68

Report on the Thematic Strategy on the Prevention and Recycling of Waste, 19.1.2011, $\operatorname{COM}(2011) 13$

Report to the European Council on the Adaptation of Community Legislation to the Subsidiarity Principle, COM (93) 545 35

Report Under Article 14(2) of Directive 2004/35/CE on the environmental liability with regard to the prevention and remedying of environmental damage', Brussels, 12.10.2010, COM(2010) 581 $115-16$

Second Regulatory Review on Nanomaterials, Brussels, 3.10.2012, COM(2012) 572

Taking sustainable use of resources forward: A Thematic Strategy on the prevention and recycling of waste, 21.12.2005,COM(2005) 666 109

Towards a European strategy for nanotechnology, Brussels, 12.5.2004, COM(2004) 338 86,146

Towards a European strategy for the security of energy supply, Brussels, 29.11.2000, $\operatorname{COM}(2000) 769$ $63-4$

\section{EUROPEAN COUNCIL}

Conclusions of 4 February 2011, 8 March 2011, EUCO 2/1/11 REV 1 5 


\section{EUROPEAN PARLIAMENT}

Assessment of the Effects of Certain Public and Private Projects on the

Environment: Provisions concerning the Quality of the EIA COD 2012/

0297

Draft Opinion on Supporting Early Demonstration of Sustainable Power

Generation from Fossil Fuels, (2008/2140(INI)), 23.7.2008.

Resolution of 24 April 2009 on regulatory aspects of nanomaterials, P6

TA(2009)0328

\section{TABLE OF EUROPEAN LEGISLATION}

Council Resolutions on energy and the environment [1975] OJ C 168/2 (3 March 1975)

\section{Directives}

77/388/EEC on the harmonization of the laws relating to turnover taxes - 6th VAT

Directive [1977] OJ L145/1

$89 / 391 / \mathrm{EEC}$ on the introduction of measures to encourage improvements in the safety and health of workers at work, [1989] OJ L 183/1

91/414/EEC concerning the placement of plant protection products on the market, [1991] OJ L 230/1

92/43/EEC on the conservation of natural habitats and of wild fauna and flora [1992] OJ L 206/7 $56-7,60$

96/82/EC on the control of major-accident hazards involving dangerous substances, [2007] OJ L 10/3,

98/8/EC concerning the placement of biocidal products on the market, [2007] OJ L $247 / 21$ $141-2$

2000/60/EC establishing a framework for Community action in the field of water policy, [2000] OJ L 327/1

2001/37/EC on the approximation of the laws, regulations and administrative provisions of the Member States concerning the manufacture, presentation and sale of tobacco, [2001] OJ L 194/26.....

2001/42/EC on the assessment of the effects of certain plans and programmes on the environment, [2001] OJ L 197/30

2001/80/EC on the limitation of emissions of certain pollutants into the air from large combustion plants, [2011] OJ L 309/1

2002/30/EC on the establishment of rules and procedures with regard to the introduction of noise-related operating restrictions at Community airports, [2002] OJ L 85/40

2003/87/EC establishing a scheme for greenhouse gas emission allowance trading within the Community and amending Council Directive 96/61/EC, [2003] OJ L 275/32 28

2003/96/EC restructuring the Community framework for the taxation of energy products and electricity, [2003] OJ L 283/51 
2004/35 on environmental liability [2004] OJ L 143/56 .................................... 57

2006/12/EC on waste, [2006] OJ L 114/9 ...................................................... 7

2006/21/EC on the management of waste from extractive industries and amending

Directive 2004/35/EC, [2006] OJ L 102/15 ................................................ 165

2007/47/EC concerning medical devices [2007] OJ L 247/21 ....................... 141-2

2008/1/EC on integrated pollution prevention and control (IPPC Directive) [2008]

OJ L 24/8 $146,164-5$

2008/50/EC on ambient air quality and cleaner air for Europe [2008] OJ L $152 / 1$

2009/28/EC on the promotion of the use of energy from renewable sources [2009]

OJ L 140/16 $28,45,57-8$

2009/31/EC on the geological storage of carbon dioxide [2009] OJ L 140/114 ..... 7 , $28,119-22,129$

2009/72/EC concerning common rules for the internal market in electricity, [2009]

OJ L211/55

27,49

2009/73/EC concerning common rules for the internal market in natural gas, [2009]

OJ L211/94 27,49

2010/31/EU on the energy performance of buildings, [2010] OJ L 153/13 ........... 70

2010/75/EU on industrial emissions OJ L 334/17 108

2011/92/EU on the assessment of the effects of certain public and private projects on the environment, [2012] OJ L 26/1 $54-6,122,125,190$

2012/27/EU on energy efficiency [2012] OJ L 315/1 45,70

draft Directive on the geological storage of carbon dioxide, Brussels, 23.1.2008,

$\operatorname{COM}(2008) 18$

\section{Regulations}

$528 / 2012$ concerning the making available on the market and use of biocidal products, [2012] OJ L 167/1 23,146

$713 / 2009 /$ EC establishing an agency for the cooperation of energy regulators, [2009] OJ L211/1

$714 / 2009 / \mathrm{EC}$ on conditions for access to the network for cross-border exchanges in electricity, [2009] OJ L211/15

$715 / 2009$ on conditions for access to the natural gas transmission networks and repealing Regulation (EC) No 1775/2005, [2009] OJ L 211/36 27,49

994/2010 concerning measures to safeguard security of gas supply [2010] OJ L $295 / 1$ 42,66

1013/2006 on shipments of waste [2006] OJ L 190/1 122

$1169 / 2011$ on the provision of food information to consumers [2011] OJ L 304/ 18

1223/2009 on cosmetic products, [2009] OJ L 342/59 $141-2$

$1907 / 2006$ concerning the registration, evaluation, authorisation and restriction of chemicals (REACH Regulations) and establishing a European Chemicals Agency [2006] OJ L396/1 86 draft Regulation on medical devices, Brussels, 26.9.2012, COM(2012) 542 ...... 146 


\section{TABLE OF NATIONAL LEGISLATION}

\section{France}

Decree No. 2012-232 on the mandatory reporting of nanomaterials

\section{TABLE OF TREATIES}

Draft European Constitutional Treaty (TCE) (29 October 2004) .................. 26, 53

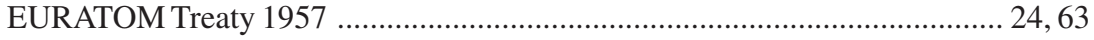

European Coal and Steel Community Treaty 1951 (ECSC) ........................ 24, 63

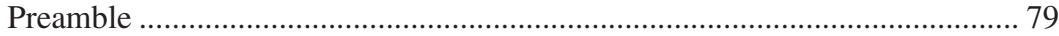

Single European Act 1986

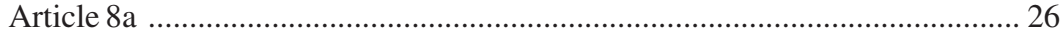

Article 130r-130t …..................................................................... 22, 53

TFEU (Treaty of the Functioning of the European Union) 2009

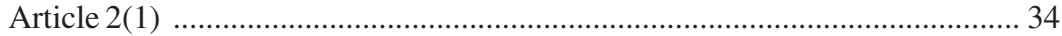

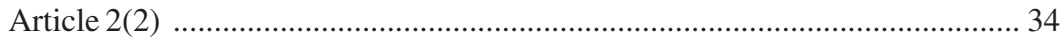

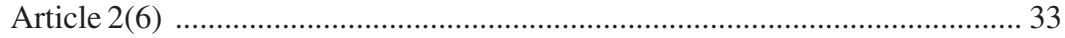

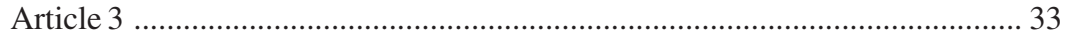

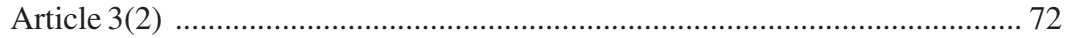

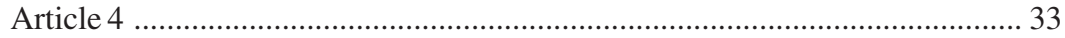

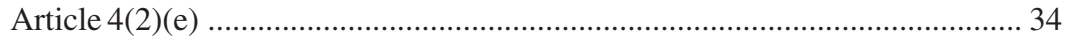

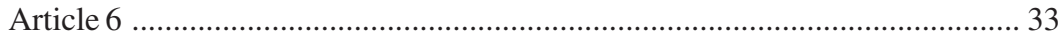

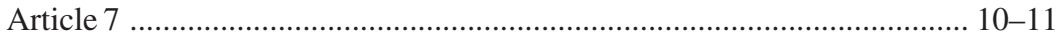

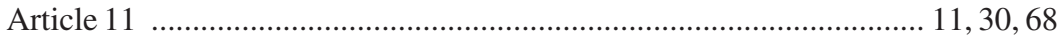

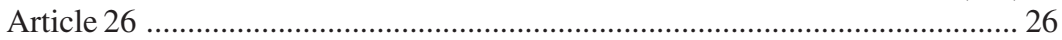

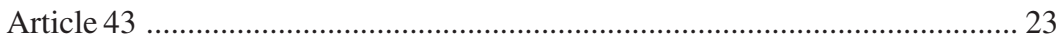

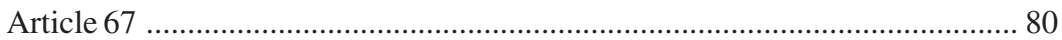

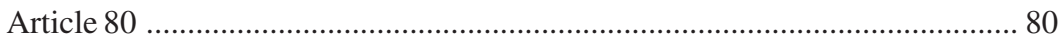

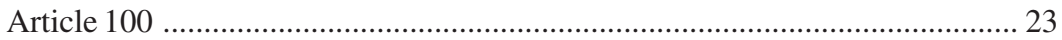

Article 101-106 f................................................................... 28

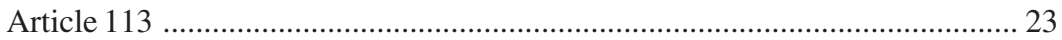

Article 114 ................................................................ 22, 23, 26, 49-50

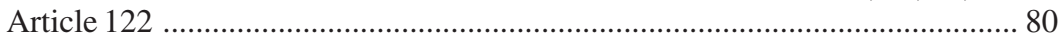

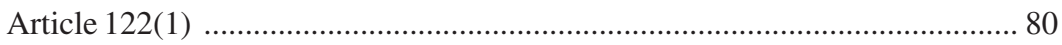

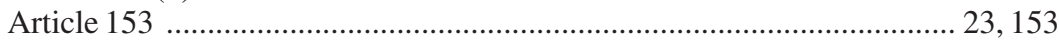

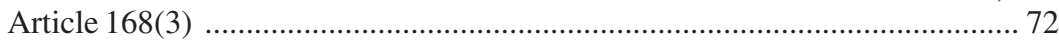

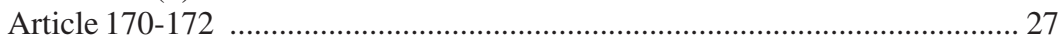

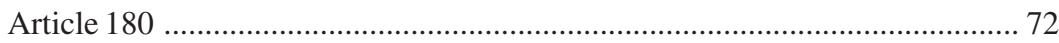

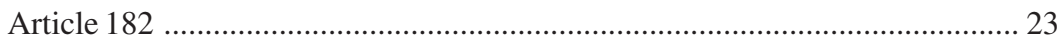

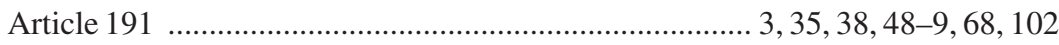

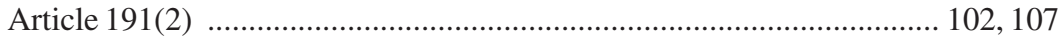

Article 192 ............................................... 27-9, 45-6, 50-51, 57-8, 60

Article 192(2)(c) …................................................... 50-52, 57, 60, 187

Article 194 ......................... 4, 28, 30-31, 35, 40-43, 45-53, 57-9, 72, 79-82 
Article 194(1) $41-3,58-9,72$

Article 194(2) $30,41,50-52,58,81-2,185-6$

Article 196 24

Article 207 $23-4$

Article 211 72

Article 214 24

Article 222 $4,80,81-2$

Article 292 $34,39,41$

Article 347 80

Article 352 $22,27,48$

Declaration 35

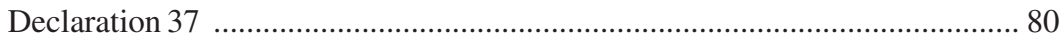

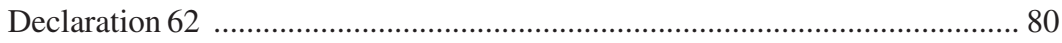

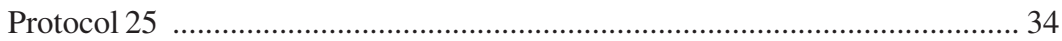

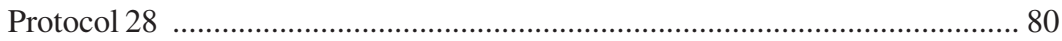

Treaty Establishing the European Economic Community 1957 (TEC)(Treaty of Rome)

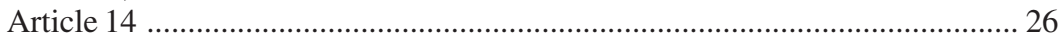

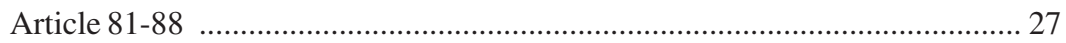

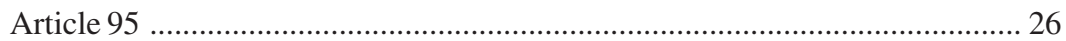

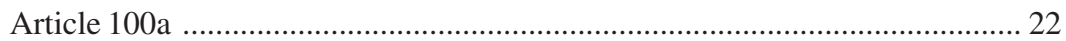

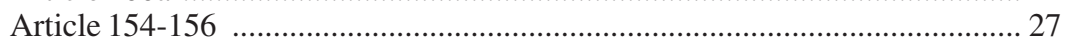

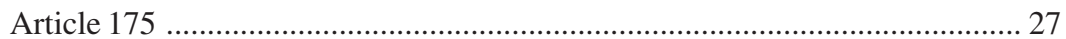

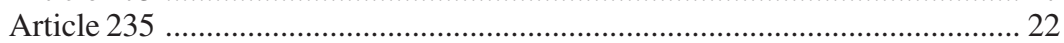

Article 308 ...................................................................................................... 27

Treaty Establishing the European Community 1992 (ECT)(Maastricht Treaty) 25,63

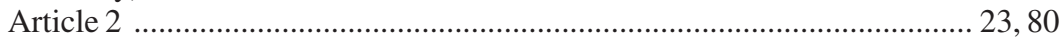

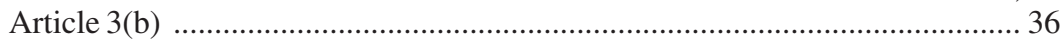

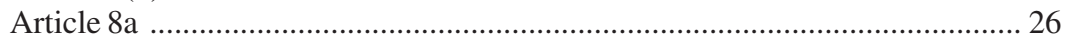

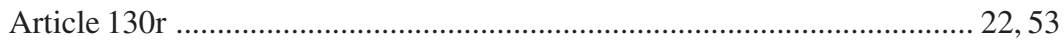

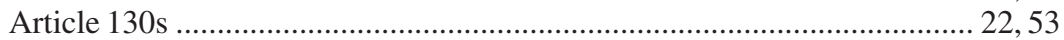

Article 130t ....................................................................... 22, 53

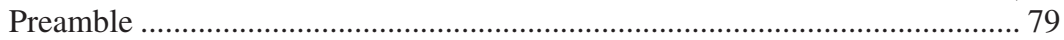

Treaty on European Union 1997 (TEU)(Amsterdam Treaty)

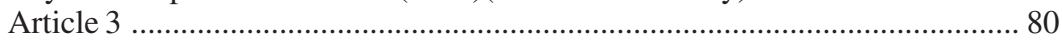

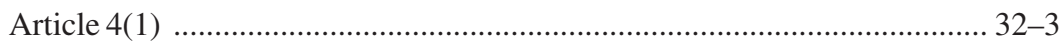

Article 5(3) ................................................................................ 36

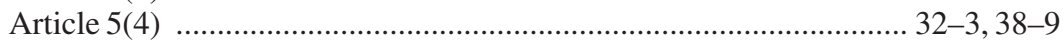

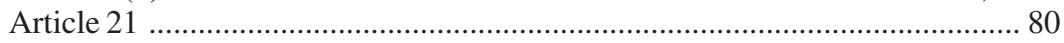

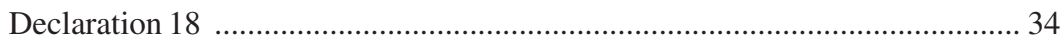

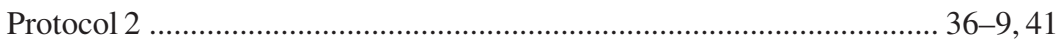

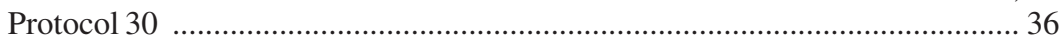

